\title{
Review of the Philippine Chalybion Dahlbom, 1843 with descriptions of two new species and one new distributional record
}

\author{
Kristine O. Abenis ${ }^{1}$ and Ireneo L. Lit, Jr. ${ }^{1,2}$
}

\begin{abstract}
Two species, Chalybion clarebaltazarae sp. nov., and Chalybion stephenreyesi sp. nov., are described as new to science on the basis of their placoid pattern and shape of genitalia. Chalybion japonicum (Griboldo, 1882) is also hereby reported as a new record for the Philippines.
\end{abstract}

Keywords: Sceliphrini, Chalybion clarebaltazarae, Chalybion stephenreyesi, Chalybion japonicum

\section{Introduction}

Sphecidae is composed of four subfamilies namely Ammophilinae, Chlorionthinae, Sceliphrinae and Sphecinae. Sceliphrinae, formerly spelled as Sceliphroninae in a number of publications, has two tribes namely, Podiini and Sceliphrini, the latter composed of two genera, Chalybion Dahlbom, 1843 and Sceliphron Klug, 1801 (Pulawski 2018). In the Philippines, many species under the tribe Sceliphrini have been recorded since 1900s (Ashmead 1894, 1904; Williams 1919). In total, there are 47 Chalybion species recorded worldwide (Pulawski 2019) of which four were recorded in the Philippines. This genus is easily identified by the absence of propodeal enclosure, subequal lengths of flagellomeres 1 and 2, presence of placoids on the antennae in males, and metallic blue color.

Examination of specimens deposited in the University of the Philippines Los Baños Museum of Natural History (UPLB$\mathrm{MNH})$ revealed two undescribed species of Chalybion, hereby named Chalybion clarebaltazarae sp. nov. and Chalybion stephenreyesi sp. nov. New nest and specimen collections from Batanes revealed the occurrence of Chalybion japonicum

\footnotetext{
${ }^{1}$ Environmental Biology Division, Institute of Biological Sciences (IBS), College of Arts and Sciences (CAS), University of the Philippines Los Baños (UPLB), College, Laguna;

${ }^{2}$ Entomology Section, Museum of Natural History, University of the Philippines Los Baños (UPLB), College, Laguna;

*Corresponding email: koabenis@up.edu.ph

Date Submitted: 11 August 2019

Date Accepted: 04 April 2020
}

(Griboldo) in the Philippines.

\section{Materials and Methods}

\section{Collection Methods, Loans and Repository of Specimens}

Nests and adults of sphecids were collected from Mt. Makiling, Los Baños, Laguna, UP Land Grant, Real, Quezon and Batanes. The nests were carefully detached from crevices, boulders and walls and were brought to the University of the Philippines Los Baños Museum of Natural History (UPLB$\mathrm{MNH}$ ) for adult emergence and the adults were collected in the field using sweep net method. Collections from Mt. Makiling, Los Baños, Laguna and UP Land Grant, Real, Quezon were deposited in UPLB-MNH and those from Batanes in the Philippine National Museum (PNM), Manila. Specimens of the Sceliphrini deposited in UPLB-MNH and PNM were also loaned for examination.

\section{Identification and Description}

Each specimen was identified using available key of Hensen (1988). Species descriptions and illustrations were compared with actual specimens. Characters were described individually and measurements of quantitative traits like flagellar ratio (FR), orbital ratio (OR), clypeal ratio (CR), hypostomal cavity ratio (HCR), mesosomal ratio (MR) and petiolus-basitarsal ratio (PBR), were computed following the approach of Hensen (1988).

To verify the identification, specimens were compared with the types which were loaned from depository museums, namely, the National Museum of Natural History, Smithsonian Institution (USNM/SI) in Washington, D.C., and the Rijksmuseum van Natuurlijke Histoire (Royal Museum of 
Natural History -- RMNH/ML), Leiden, The Netherlands.

Names were given to new species discovered in accordance with the International Code of Zoological Nomenclature (ICZN) and a key to Philippine taxa was provided.

Synonymous names were provided for each species and for full bibliographic citation, readers are referred to the catalog for Sphecidae available online in the research archive of the California Academy of Sciences (Pulawski 2019).

\section{Processing of Genitalia}

Since the configuration of the male genitalia is an important character in in identifying Chalybion species, at least one specimen for each species was dissected and processed using the methods of Melo (1999).

\section{Taxonomy}

\section{Key to species of Chalybion Dahlbom, 1843}

1 Tarsi with plantulae. .2

- Tarsi without plantulae 4

2 Hind tarsal claw with subbasal tooth.

C. bengalense

\section{(Dahlbom)}

- Hind tarsal claw without subbasal tooth. .3

3 Frons reticulate rugose, mesoscutum transversely strigose, laterally and posteriorly with additional punctation

C. polyphemus Hensen

- Frons and mesoscutum coarsely punctate.

... clarebaltazarae sp. nov.

4 Hind tarsal claw with subbasal tooth..

C. magnum Hensen

- Hind tarsal claw without subbasal tooth.

.5

5 Pronotum densely strongly punctate without shallow striae......................................... japonicum (Griboldo)

- Pronotum finely punctate with or without shallow striae.......6

6 Frons coarsely punctate, pronotum with shallow punctures and striae; males have placoids on flagellomeres 5 to 9 .

C. vechti Hensen

- Frons rugose-punctate, pronotum finely punctate; males have placoids on flagellomeres 5 to 8 .

C. stephenreyesi sp. nov.

\section{Chalybion bengalense (Dahlbom)}

Sphex violacea Fabricius, 1775: 346 [nec Sphex violacea Scopoli, 1763].

Pelopoeus (Chalybion) bengalensis Dahlbom, 1845:433.

Pelopoeus violaceus (Fabricius): Costa [1864] 1867: 76.

Sceliphron (Chalybion) bengalense Dahlbom: Kohl 1918: 34,
41, 54; Ashmead 1904: 6.

Chalybion violaceum (Fabricius): Williams 1919: 119

Sceliphron (Chalybion) violaceum (Fabricius): Ashmead 1904:

6; Rohwer (1921) 1922: 674.

Diagnosis: The species is distinguished from its congeners by the presence of apicolateral tuft of tomentum in the propodeum, hyaline wings with brown apical spot and normal ocelli. Males are easily identified by the placoids on flagellomeres 5 to or 6 to 9 while females have a small patch of micropubsecence on the anterior part of the $4^{\text {th }}$ sternite.

\section{Description:}

Size: Body length $q 13$ to $18 \mathrm{~mm}$, o 10 to $16 \mathrm{~mm}$; length of forewing $q 8$ to $12 \mathrm{~mm}, \widehat{\partial} 7$ to $11 \mathrm{~mm}$.

Head: Antennae ${ }^{\lambda}$ with placoids on flagellomeres 5 to or 6 to 9 ; ocelli normal; frons densely coarsely punctate to rugosepunctate; clypeus finely punctate, $\delta$ three small teeth, $q$ five lobes with median lobe narrower and lateral lobes rounder (Hensen 1988).

Mesosoma: Pronotum sparsely finely punctate; mesoscutum sparsely finely to coarsely punctate; mesopleuron densely coarsely punctate to rugose punctate; scutellum and metanotum sparsely finely punctate; metapleuron anteriorly finely punctate, posteriorly with large punctures with large smooth area; propodeum medially transversely strigose with shallow punctures in between, laterally rugose-punctate outside

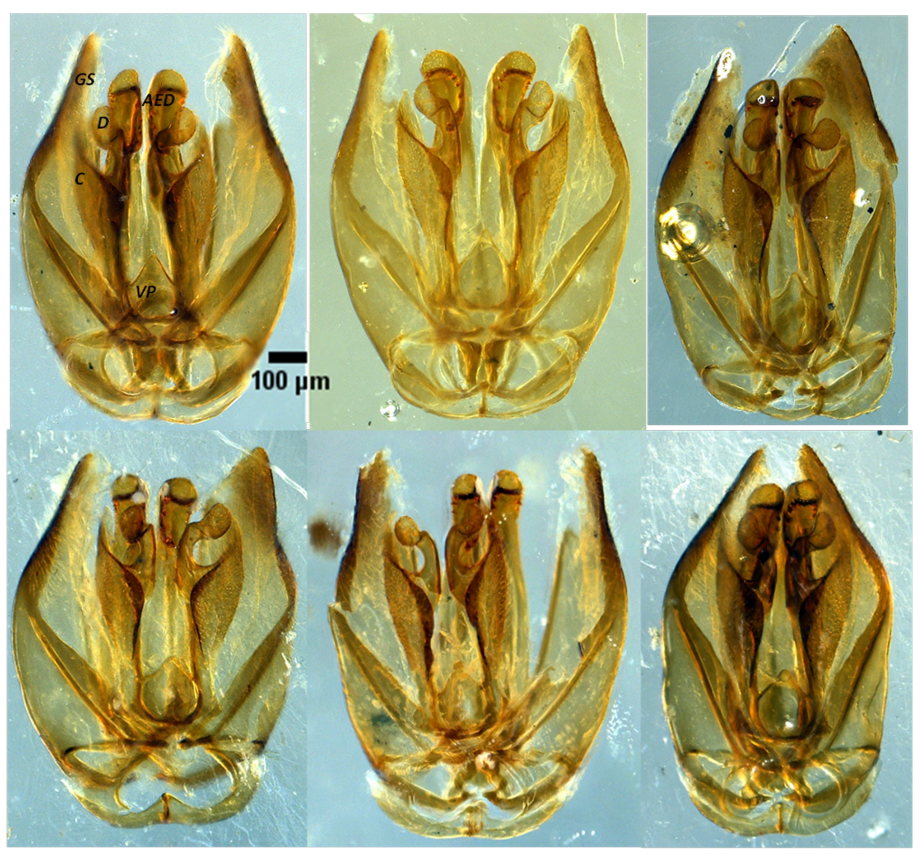

Figure 1. Variation in genitalic structures in Chalybion bengalense: $G S$-gonostyle, $A E D$-aedeagus, $D$-digitus and $C$ - cuspis $(D+C$ $=$ volsella), $V P$ - volsellar plate. 


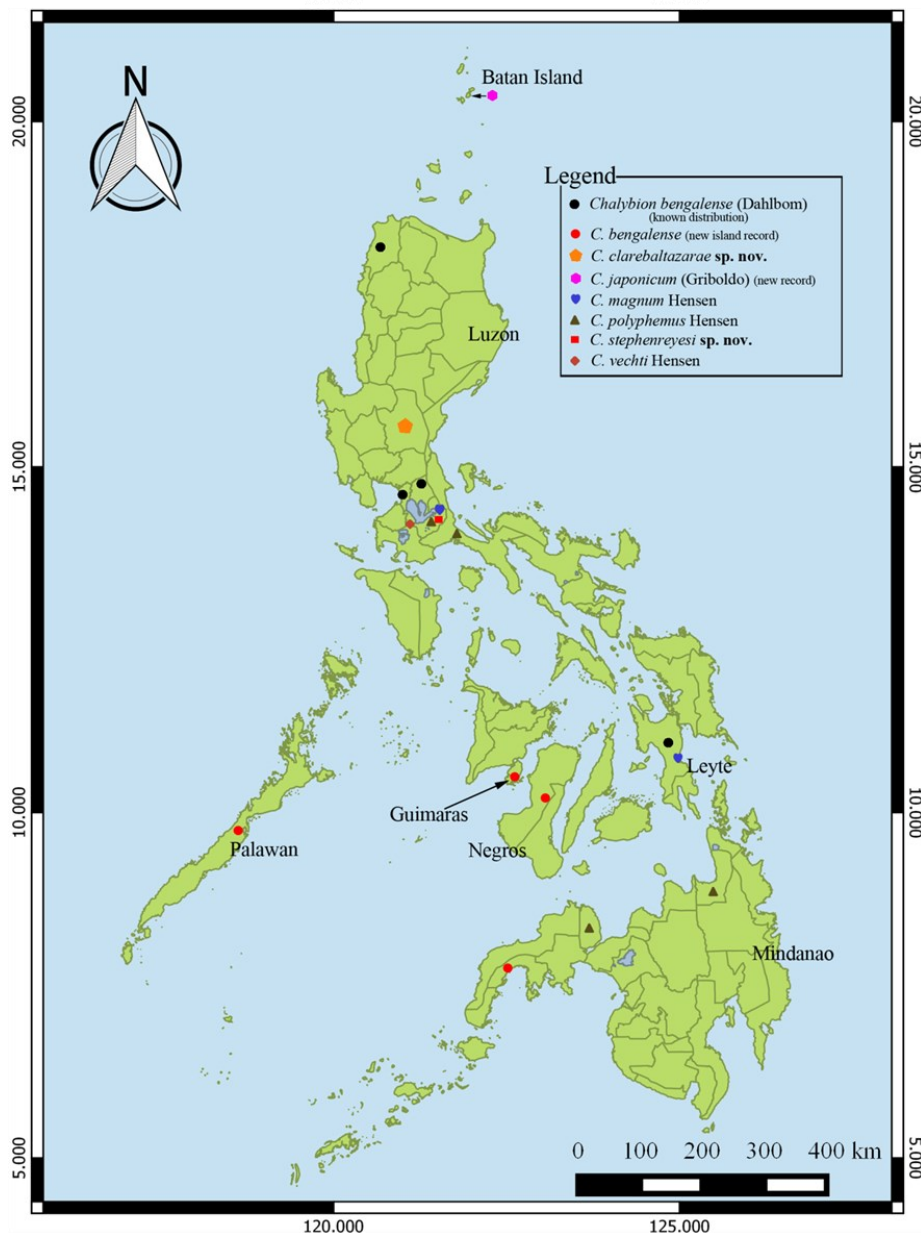

Figure 2. Distribution of all Chalybion species in the Philippines.

propodeal enclosure; tarsal claws with small inner subbasal tooth; plantulae present (Hensen 1988).

Metasoma: of without cerci, aedeagus with a row of teeth along the ventral margin, volsellar plate variable (Fig. 1); 우 with small patch of micropubescence on anterior part of $4^{\text {th }}$ sternite (Hensen 1988).

Distribution: Cosmopolitan: Oriental Region, New Guinea, Australia, Eastern Africa, Islands in Indian and Pacific Oceans (Hensen 1988), Mediterranean and Europe (Mei et al. 2012), Philippines: Luzon, Leyte (Hensen 1988), New island records: Palawan, Negros Occidental, Guimaras, Zamboanga del Sur (Fig. 2).

Remarks: Some specimens have rounder volsellar plate compared to those of others which are elongated.

This species had already been recorded preying on larvae and pupae of the Asian corn borer, Ostrinia furnacalis (Guenee), in the Philippines (Camarao 1976).

\section{Material examined:}

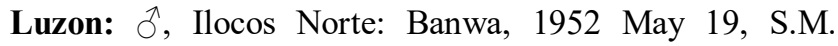
Cendaña (UPLBMNH HYM-02380); ô, Isabela: Ilagan, 1951

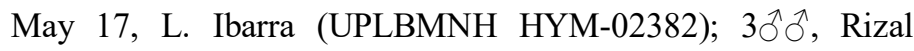
Province: Pasig, 1953 July 9, P.C. Feliciano (UPLBMNH HYM -02396); 1953 October 19, F.R. Candelaria (UPLBMNH HYM02407); 1953 August 28, F.R. Candelaria (UPLBMNH HYM02400); 8ภํ, 4우, Laguna Prov: Los Baños: 1997 January 19, Zahid (UPLBMNH HYM-02399); 1954 March 4, C.R. Baltazar (UPLBMNH HYM-02401); 1954 February 2, M. Delfinado (UPLBMNH HYM-02403); 1975 August 15, G. Camarao (UPLBMNH HYM-02412); 1957 May 5, F.M. Delmo (UPLBMNH HYM-02415); 1960 April 20, S.G. Fajardo (UPLBMNH HYM-02417); 1960 June 12, D. del Rosario (UPLBMNH HYM-02419); 1957 September 22, F. M. Delmo (UPLBMNH HYM-02421); 1953 March 15, F. de Guzman (UPLBMNH HYM-02402); 1982 September 2, C.D. Ubiña (UPLBMNH HYM-02404); 1963 October 7, F.R. Candelaria (UPLBMNH HYM-02405); 1963 April 21, M.L. Pescador (UPLBMNH HYM-02422); ${ }^{\lambda}$, Laguna Prov: Sta. Rosa, 1972 May 10, A.M. Adato (UPLBMNH HYM-02411).

Palawan: Ô, Puerto Princesa, Palawan, 1983 May 19, R.A. Casiñas (UPLBMNH HYM-02495) (new island record).

Visayas Island Group: $\widehat{\partial} \hat{\partial}$, Negros Is: San Carlos, P.I., 1953 July 26, R. Valmayor (UPLBMNH HYM-02372-2373) (new island record); $\widehat{\jmath}$, Guimaras: Jordan, 1985 March 17, C. R. Baltazar (UPLBMNH HYM-02490) (new island record).

Mindanao: $\widehat{O}$, Zamboanga del Sur: Betinan, San Miguel, P.I., 1985 October 21, E.C. Mituda (UPLBMNH HYM-02398) (new island record).

\section{Chalybion polyphemus Hensen}

Chalybion polyphemus Hensen 1988: 27, Holotype: + , Philippines: Luzon: Quezon Province: Atimonan (RMNH)

Diagnosis: This species is characterized by the absence of inner subbasal tooth in the tarsal claws. The males are easily distinguished by the absence of placoids in the flagellomeres and the females by the presence of a small transverse patch of micropubescence on the fourth sternite.

\section{Description:}

Size: Body length, o 14.3 to $15.5 \mathrm{~mm}$, त $12.3 \mathrm{~mm}$; length of forewing + 10.2 to 10.4, $\widehat{\jmath} 8.4 \mathrm{~mm}$ (Hensen 1988).

Head: Antennae of males without placoids; frons strongly reticulate-rugose; ocelli reduced, sunken in surrounding structure; clypeus nearly flat, $\widehat{\delta} 3$ teeth, $q 5$ teeth (Hensen 1988). 
Mesosoma: Pronotum densely coarsely punctate; mesoscutum transversely strigose, laterally and posteriorly with additional punctures; scutellum and metanotum punctate; propodeum anteriorly transversely strigose-punctate; plantulae present; tarsal claws without inner subbasal tooth (Hensen 1988).

Metasoma: Petiole longer than hind basitarsus; fourth sternite of female with spot of micropubescence; eighth tergite of male without cerci; aedeagus of male without teeth on ventral margins (Hensen 1988).

Distribution: Philippines: Luzon, Mindanao.

Remarks: This is known only from the type series. Hensen (1988) did not mention about the texture of the pronotum in his description but the images of holotype and paratype provided by RMNH had its pronotum densely coarsely punctate.

\section{Material examined:}

Holotype (images provided by RMNH): Philippine Islands, Luzon, Quezon Province, Atimonan, July 1963, Concepcion.

Paratype (images provided by RMNH): Philippines Luzon Mt. Makiling Laguna, 23 March 1934, S.R. Capco.

\section{Chalybion clarebaltazarae, sp. nov.}

Diagnosis: Males of this species are close to Chalybion bengalense but can be differentiated from other Chalybion species by the presence of placoids in flagellomeres 7 to 9 . The female is not known.

\section{Description:}

Size: Body length, o $12 \mathrm{~mm}$; length of forewing ㅇ $9 \mathrm{~mm}$ (Fig. 3).

Head: Frons coarsely punctate; inner eye orbit emarginate; ocelli normal; clypeus coarsely punctate with 3 lobes close to each other; flagellomeres 1 and 2 equal; placoids present on flagellomeres 7 to 9 (Fig. 3c).

Mesosoma: Pronotum, scutum and scutellum coarsely punctate; metanotum finely punctate; mesopleuron and metapleuron densely coarsely punctate; propodeum anteriorly striate, becoming coarsely punctate from median to posterior mesosoma; laterally coarsely punctate; tarsi with plantulae; tarsal claws not toothed.

Metasoma: Length of petiole sub-equal to hind basitarsus; Second and third visible abdominal sternite with a row of punctures posteriorly; gonostyle shorter than aedeagus; volsella dilated; aedeagus with teeth along ventral margin (Fig. 3d).

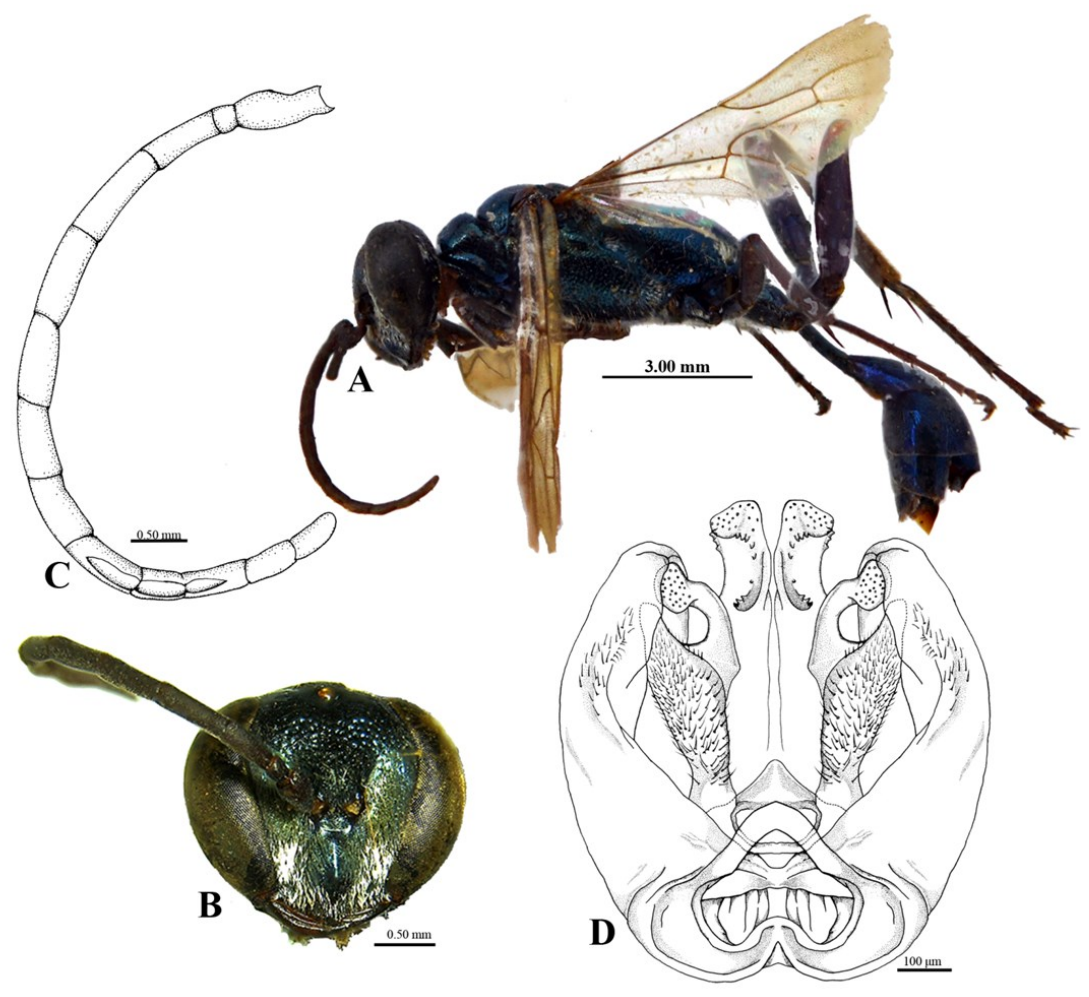

Figure 3. Chalybion clarebaltazarae, sp. nov.: A. lateral habitus; B. full-face view; C. illustration of its antenna showing the placoids at flagellomeres 7 to 9 ; and D. line drawing of the male genitalia. 
Indices: MALE: FR 1.0; OR 1.25; CR 1.6; HCR 1.25; MR 2.5; PBR 1.0.

Distribution: Luzon: Nueva Ecija.

Remarks: The female is not known.

Etymology: This species is named after the first Filipina entomologist and Filipino hymenopterist, National Scientist Dr. Clare R. Baltazar.

\section{Material Examined:}

Holotype: đ, BFD, Sta. Puncan, Carranglan, Nueva Ecija Province, Philippines, 1981 September, M. D. Malabayabas (UPLBMNH HYM-02489).

\section{Chalybion magnum Hensen}

Chalybion magnum Hensen 1988 :34, Holotype: + , Philippines: Luzon: Mount Makiling (USNM).

Diagnosis: This is a large species easily characterized by its clypeus which has median and submedian lobes fused to a single broad lobe that appears flat and sharp lateral lobes projecting divergently. The male of this species is not known.

\section{Description:}

Size: Body length, ㅇ 20.5 to $24.5 \mathrm{~mm}$, length of forewing q 15.5 to $18.0 \mathrm{~mm}$.

Head: Ocelli reduced; frons punctate-reticulate; clypeus densely coarsely punctate, median and submedian lobes fused to a single broad lobe appearing flat, lateral lobes sharp projecting divergently (Hensen 1988).

Mesosoma: Pronotum sparsely punctate with traces of transverse striae; mesoscutum densely, coarsely punctate, posteriorly with faint transverse striae; scutellum and metanotum finely punctate; mesopleuron densely coarsely punctate; lower metapleural area with strong striae and upper metapleural area finely punctate; propodeum strongly striate with fine punctures in between, with dense strong punctures laterally (Hensen 1988).

Metasoma: Petiole weakly curved, shorter than hind basitarsus; fourth sternite without micropubescence (Hensen 1988).

Distribution: Philippines: Luzon: Laguna; Visayas: Samar, Leyte, Sibuyan.

Remarks: This species is known only from type series.
The holotype has the ocelli sunk below surrounding integument while the paratype has normal visible flat ocelli (Fig. 4).

The left wing of the holotype also has a third recurrent vein which is received by third submarginal cell resulting to the formation of a third discoidal cell (Fig. 4).

The mesoscutum of the paratype is strigose and its whole propodeum strongly striate.

Hensen (1988) did not describe the metanotum. It is here noted as densely finely punctate, and that plantulae are also absent and tarsal claws have inner claw.

\section{Material examined:}

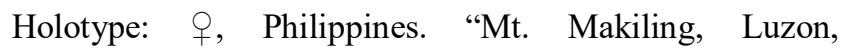
Baker" (USNM/SI).

Paratype (images provided by RMNH): + , Philippines, Leyte, Mt. Pangasugan, 200 m, 7 May 1952, F. Baseng.

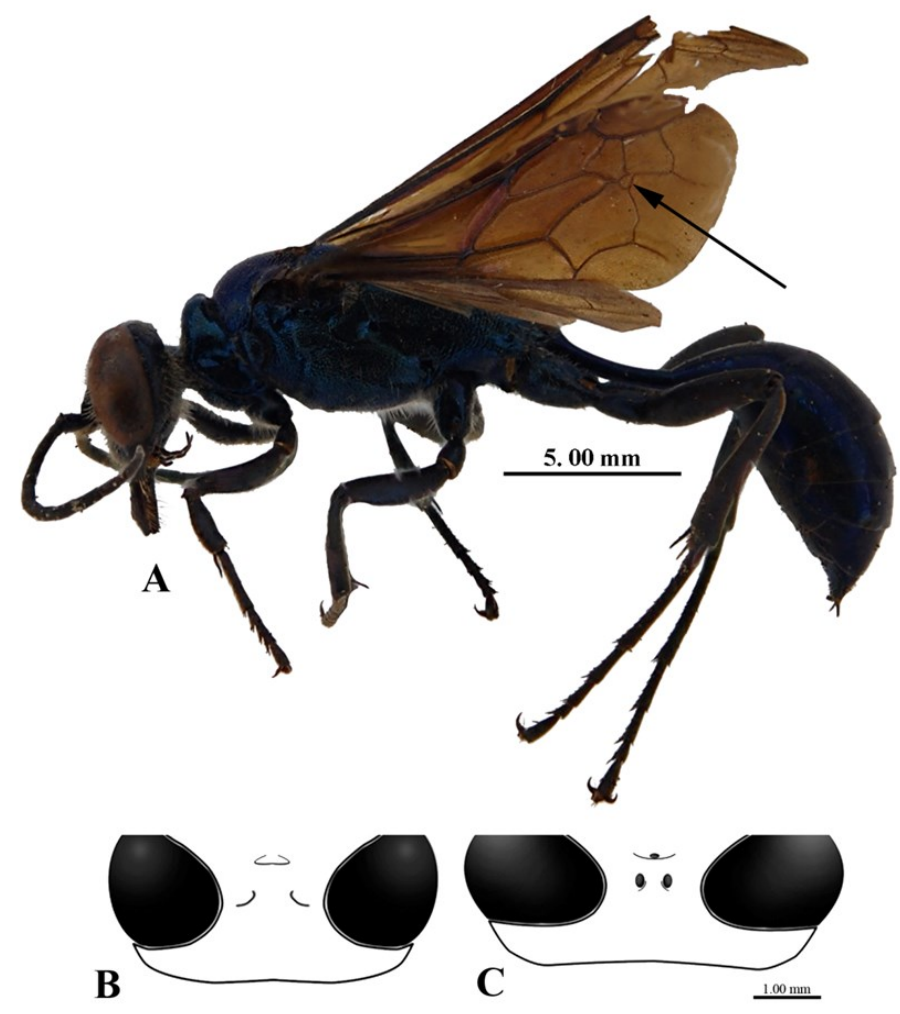

Figure 4. Chalybion magnum Hensen: A. Left forewing of Chalybion magnum showing the presence of a third discoidal cell (arrow); B. head of Chalybion magnum showing the ocelli of holotype; and C. paratype. 


\section{Chalybion japonicum (Griboldo)}

Chalybion japonicum (Griboldo, 1883), Lectotype: ㅇ, Japan: no specific locality (RMNH), designated by Hensen 1988: 54.

Diagnosis: This species is easily recognized by its bulging ocelli and strong dense punctures in pronotum, mesoscutum and metanotum.

\section{Description:}

Size: Body length $+17 \mathrm{~mm}$; Wing span $\circ 12.7 \mathrm{~mm}$

Head: Ocelli bulging; frons and clypeus strongly densely punctate; clypeus with five lobes (Fig. 5).

Mesosoma: Pronotum, mesoscutum, mesopleuron, metanotum and metapleuron strongly punctate; propodeum transversely strigose-punctate; wings gray; plantulae absent; hind tarsal claw without inner subbasal tooth.

Metasoma: Petiole strongly curved; fourth sternite covered with micropubescence (Fig. 5).

Distribution: China, Korea, Japan, Taiwan, Thailand, Vietnam (Hensen 1988; Barthelemy 2011), and Philippines (new record).

Remarks: Specimens examined were identified as females of Chalybion japonicum (Griboldo) using the key of Hensen (1988). This species is hereby reported as a new record for the Philippines. The Philippine specimens, however, possess greyish wings as compared to those examined by Hensen which have brownish wings.

Material examined: $ㅇ+q$, N.M. Barbecho and J.B. Baroga, 22 March 2016, Mahatao/Uyugan, Basco, Batanes, Philippines (PNM13473-13475).

\section{Chalybion vechti Hensen}

Chalybion vechti Hensen 1988: 56; Holotype: $ᄋ$, Philippines: Los Baños (RMNH).

Diagnosis: This species is close to Chalybion bengalense but can be recognized by the presence of reduced ocelli and faint transverse striae in the pronotum. The males are easily identified by the presence of placoids on flagellomeres 5 to 9 and females by large patch of pubescence on the fourth sternite.

\section{Description:}

Size: Body length + 15.5 to $18.0 \mathrm{~mm}$, ô 11.7 to $13.6 \mathrm{~mm}$;

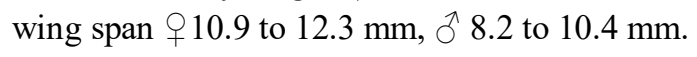

Head: Antennae of males with placoids on flagellomeres 5

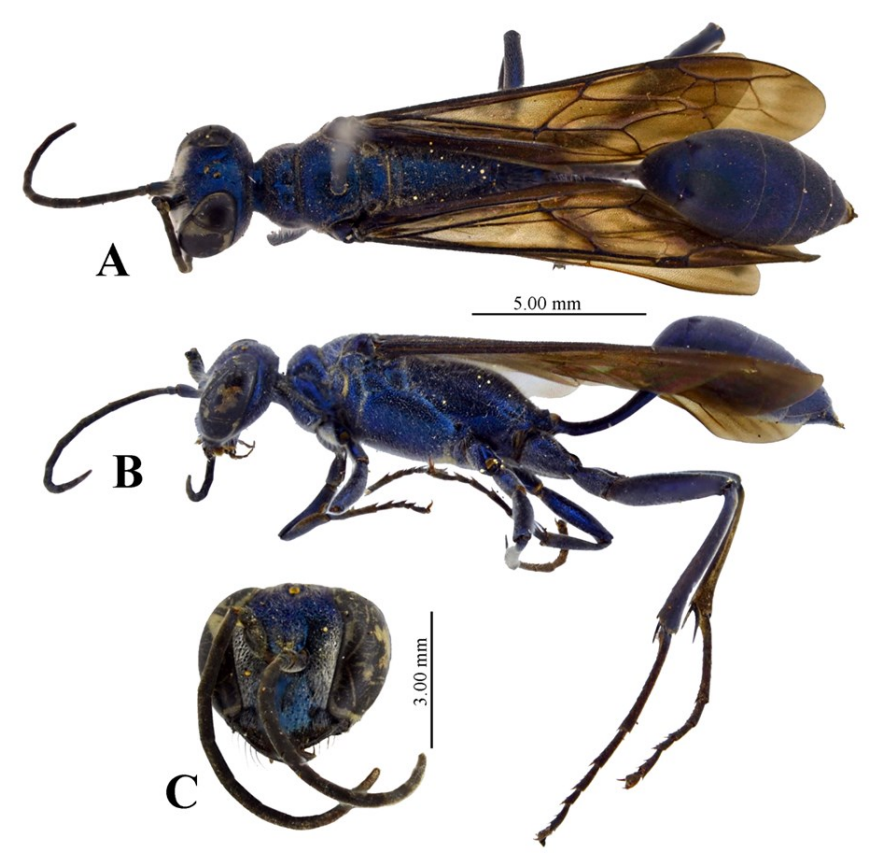

Figure 5. Chalybion japonicum (Griboldo): A. dorsal habitus; B. lateral habitus; and C. full-face view.

to 9; ocelli reduced; frons densely coarsely punctate; clypeus sparsely punctate, $\delta$ three small teeth, $q$ five small lobes, median lobe narrower than submedian (Hensen 1988).

Mesosoma: Pronotum with shallow punctures and striae; mesoscutum densely coarsely punctate; metanotum punctate; propodeum medially transversely strigose, laterally rugosepunctate; plantulae absent; hind tarsal claws without inner subbasal tooth (Hensen 1988).

Metasoma: Petiole weakly curved, as long as hind basitarsus; fourth sternite of female covered with micropubescence; aedeagus with teeth along ventral margins (Hensen 1988).

Distribution: Philippines: Luzon.

Material examined: Holotype (images provided by RMNH): Philippines: Los Baños PI, May 30, 1915, F. Otanes; Non-types: §., Philippines: Luzon, Los Baños, Laguna, 1974 July 25, G. Camarao (UPLBMNH HYM-02408); 今̂, 1947 November 18, L.B. Uichanco (UPLBMNH HYM-02413); + 1948 October 25, L.B. Uichanco (UPLBMNH HYM-02416); + 1957 May 5, F.M. Delmo (UPLBMNH HYM-02418).

\section{Chalybion stephenreyesi, sp. nov.}

Diagnosis: This species is close to Chalybion bengalense but can be easily differentiated by the absence of plantulae. Males 


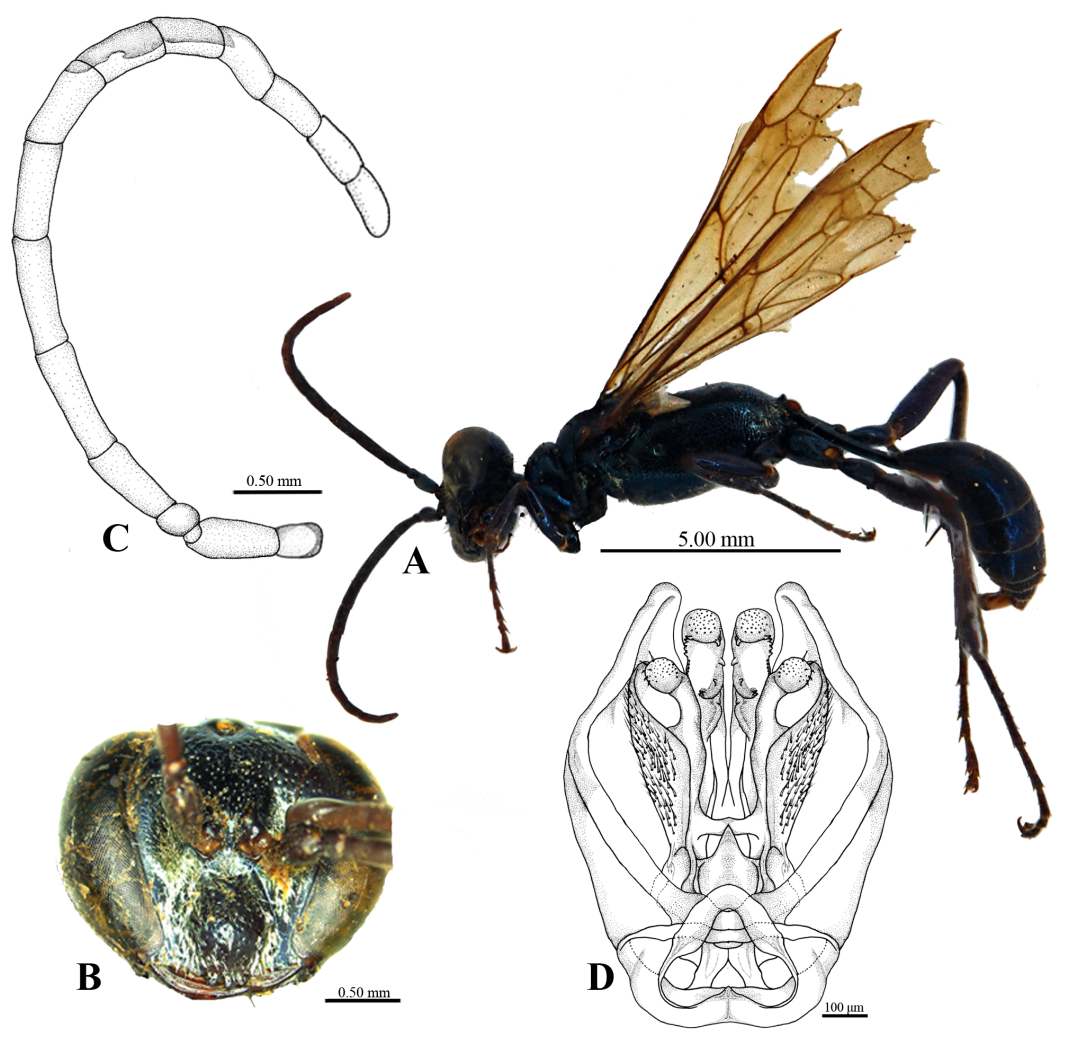

Figure 6. Chalybion stephenreyesi, sp. nov.: A. lateral habitus; B. full-face view; C. illustration of the antenna showing the placoids at flagellomeres 5 to 8 ; and D. line drawing highlighting genitalic structures.

are easily recognized by the presence of placoids on flagellomeres 5 to 8 . The female is not known.

\section{Description:}

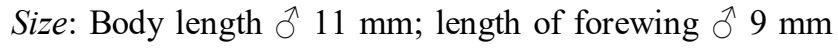
(Fig. 6).

Head: Antennae with placoids on flagellomeres 5 to 8 (Fig. 6); hind ocelli reduced; compound eyes emarginate; frons rugose- punctate; clypeus sparsely finely punctate with three lobes.

Mesosoma: Pronotum, scutum, scutellum and metanotum finely punctate; second submarginal cell of forewing anteriorly narrowed; propodeum anteriorly striate with punctures in between, eventually becoming medially finely punctate and posteriorly coarsely punctate; laterally coarsely punctate; tarsi without plantulae; tarsal claws with subbasal tooth.

Metasoma: Second and third visible abdominal sternite without row of punctures posteriorly; volsellar plate hastate (=oriented divergently) and margins pointed; volsellar cuspis without hairs on inner margins; aedeagus toothed (Fig. 6).
Indices: MALE FR --; OR 1.25; CR 0.63; HCR 1.3; MR 2.5; PBR -n/a

Distribution: Philippines: Luzon: Laguna.

Remarks: The female is not known.

Etymology: This species is named after the sphecid expert, Dr. Stephen Reyes, whose works focused mainly on the Philanthidae of the Philippines.

\section{Material examined:}

Holotype: đ, Mudspring, Mt. Makiling, Los Baños, Laguna, P.I., 1980 March 24, B. Chantana (UPLBMNH HYM02493).

Paratype: đ̂, Los Baños, Laguna, 1995 August 15, G. Camarao (UPLBMNH HYM-02406). 


\section{Acknowledgements}

The authors would like to extend their gratitude to the Department of Science and Technology-Accelerated Science and Technology Human Resource Development ProgramNational Science Consortium (DOST-ASTHRDP-NSC) for funding this study, the UPLB Museum of Natural History (UPLB MNH) and Philippine National Museum (PNM) for the loaned specimens, the Smithsonian Institution (USNM/SI) for the loaned holotype, the Rijksmuseum van Natuurlijke Histoire, The Netherlands (RMNH/ML) for the images of holotypes, paratypes and type series, Mr. Cristian C. Lucañas and Mr. Orlando L. Eusebio for the illustrations of the two new species.

\section{Literature Cited}

Ashmead, W.H., 1894. Descriptions of new genera and species of Hymenoptera from the Philippine Islands. Proceedings U.S. National Museum, 28(1387): 127-158.

Ashmead, W.H., 1904. A list of Hymenoptera of the Philippine islands, with descriptions of new species. Journal of the New York Entomological Society, 12: 1-22.

Baltazar, C.R., 1966. A catalogue of Philippine Hymenoptera. Pacific Insects Monographs, 8: 1- 488.

Barthelemy, C., 2011. Notes on the biology of the conspicuous mud dauber wasp, Chalybion japonicum (Griboldo, 1883) (Sphecidae), a major predator of spiders in Hong Kong. Hong Kong Entomological Bulletin, 3(1): 7-14.

Camarao, G.C., 1976. Population dynamics of the corn borer, Ostrinia furnacalis (Guenee), I. Life cycle, behavior and generation cycles. The Philippine Entomologist 3(3-4): 179 -200 .

Costa, A., (1864) 1867. Annuario del museo zoologico. Napoli, Anno IV. Tipografia di Antonio Cons. Strada S. Antonio alla Vicaria 44.. 102 pp.

Dahlbom A.G., 1845. Hymenoptera Europaea praecipue borealia, etc. Ex officina Lundbergiana xliv $+528 \mathrm{pp}$.

Fabricius, J.C., 1775. Systema Entomologiae, etc. Flensbvrgi et Lipsiae, In Officina Libraria Kortii xxx +882 pp.

Hensen, R.V., 1988. Revision of nominate subgenus Chalybion Dahlbom (Hymenoptera, Sphecidae). Tijdschrift voor Entomologie, 131: 13-64.

Kohl, F., 1918. Die hautflüglegruppe "Sphecinae". IV. Teil. Die natürliche Gattung Sceliphron Klug (Pelopoeus Latr.). Annalen des naturhistorischen hofmuseums 32: 1-171.

Mei, M., G. Pezzi, R. de Togni \& U. Devicenzo, 2012. The Oriental mud-dauber wasp Chalybion bengalense (Dahlbom) introduced in Italy (Hymenoptera, Sphecidae). Ampulex 5: 37-41.
Melo, G.A.R., 1999. Phylogenetic relationships and classification of the major lineages of Apoidea (Hymenoptera), with emphasis on crabronid wasps. Scientific Papers. Natural History Museum, The University of Kansas 14: 1-55.

Pulawski, W.J., 2018. Family group-names and classification as of 29 November 2018. Available from: http:// researcharchive.calacademy.org/research/entomology/ entomology_resources/hymenoptera/sphecidae/ family_group_names_and_classification.pdf. Accessed 09 August 2019.

Pulawski, W.J., 2019. Number of species as of 06 July 2019. Available from: http://researcharchive.calacademy.org/ research/entomology/entomology_resources/hymenoptera/ sphecidae/number_of_species.pdf. Accessed 09 August 2019.

Rohwer, S.A., (1921) 1922. The Philippine wasps of the subfamily Sphecinae. Philippine Journal of Science, 19: 665-676.

Williams, F.X., 1919. Philippine wasps studies. Part II: descriptions of new species and life history studies. Report of Work of the Experiment Station of the Hawaiian Sugar Planters' Association. Entomological Series Bulletin, 14: 19 $-186$. 